\title{
Effect of heat stress on Hsp90a2b and Hsp10 mRNA expression and blood cell apoptosis in rainbow trout Oncorhynchus mykiss (Walbaum, 1972)
}

\author{
ZHICHENG LUO, YANJING ZHOU, ZHE LIU, BINPENG XIA AND YONGJIE WANG \\ College of Animal Science and Technology, Gansu Agricultural University, No. 1 Yingmencun, Anning District \\ Lanzhou - 730 070, Gansu, China \\ e-mail:liuz@gsau.edu.cn
}

\begin{abstract}
To study the response to heat stress in rainbow trout Oncorhynchus mykiss (Walbaum, 1972), the expression of heat shock protein genes Hsp90a2b and Hsp10 in selected tissues and apoptosis of blood cells were investigated at water temperatures of $18,21,23,24,25$ and $26^{\circ} \mathrm{C}$. Expressions of Hsp90a2b in the gill, mid-kidney, brain, heart and muscle were generally upregulated with increasing temperature. Hsp90a2b expression in the liver increased rapidly at $21^{\circ} \mathrm{C}$ and then showed a significant decrease and finally a significant increase at $25^{\circ} \mathrm{C}$ and $26^{\circ} \mathrm{C}(\mathrm{p}<0.05)$. Hsp 10 expression showed an irregular but overall increasing tendency in gill, spleen and mid-kidney and a wave-like increasing pattern in liver, heart and muscle. Levels of $\mathrm{Hsp} 90 \mathrm{a} 2 \mathrm{~b}$ at $25^{\circ} \mathrm{C}$ and $\mathrm{Hsp} 10$ at $26^{\circ} \mathrm{C}$ in all tissues were always significantly higher compared to $18^{\circ} \mathrm{C}(\mathrm{p}<0.05)$. The apoptosis rate at $21^{\circ} \mathrm{C}$ was significantly higher than that at $18^{\circ} \mathrm{C}$, followed by a fall and was the highest at $25^{\circ} \mathrm{C}$. All these data indicated that the heat shock response already occurred at $21^{\circ} \mathrm{C}$ which induced expressions of Hsp90a2b and Hsp10 as well as blood cells apoptosis and $25^{\circ} \mathrm{C}$ may be a key temperature for stress response in rainbow trout.
\end{abstract}

Keywords: Cell apoptosis, Heat stress, Hsp90a2b, Hsp10, Rainbow trout

\section{Introduction}

Rainbow trout Oncorhynchus mykiss (Walbaum, 1972) is a typical cold water fish. This species shows optimum growth at a water temperature of $12-18^{\circ} \mathrm{C}$ and has low tolerance and high sensitivity to higher temperatures. The increasing water temperature in summer weather can affect feeding, metabolism and development, causing disease and even death of fish. This not only has welfare implications for fish but also reduces its economic value (Verleih et al., 2015).

Heat shock proteins (Hsps) are a class of highly conserved proteins that have been demonstrated to be induced in all organisms by a variety of stressors such as heat, osmotic shock, heavy metals, starvation or oxidative stress (Lindquist and Craig, 1988; Basu et al., 2002; Roberts et al., 2010). When the external temperature is within normal limits for a body, the expression level of Hsps is low. When an organism senses that the external temperature is beyond its limitation, expression increases rapidly to protect the body from damage. The Hsps are classed by molecular weight, for example Hsp100s, Hsp90s, Hsp70s, Hsp60s, small molecular family and ubiquitin and so on. According to their function and regulation, there are two categories of Hsps, constitutive (or cognate) heat-shock proteins (Hscs) and inducible heat-shock proteins (Hsps) (Lindquist and Craig, 1988; Pirkkala et al., 2000).

Hsp90a, a member of Hsp90s family, is an inducible heat-shock protein which usually exists and exerts its effect in the form of dimer. It can participate in the immune response by presenting an antigen peptide to the immunocompetent cells (Li et al., 2007) and also when cells are stimulated by an external stressor such as temperature change, the intracellular levels of denatured protein surge, protein function is lost, but at the same time Hsp90a is quickly synthesised to act as a molecular chaperone protecting the body from damage (Galea-Lauri et al., 1996). Furthermore, a recent study showed that there are four gene isoforms (Hsp90a1a, GenBank Accession no. KC150880; Hsp90a1b, Accession no. KC150881; Hsp90a2a, Accession no. KC150878 and Hsp90a2b, Accession no. KC150879) of transcripts for Hsp90a protein in the rainbow trout, owing to the whole genome duplication that occurred during the evolution of rainbow trout (Jia et al., 2016). But, in most cases, it is not known which isoforms are stress responsive. Boone and Vijayan (2002) found differences in Hsp70 mRNA isoform expression after heat shock in rainbow trout hepatocytes. The study of Jia et al. (2016) also showed that the mRNA levels of Hsp90a1b and Hsp90a2a in rainbow trout hepatocytes were significantly increased after heat shock, 
while Hsp90a1a and Hsp90a2b were unaffected by this acute hyperthermic treatment. As more than one Hsp90a isoforms exist within a species, it becomes interesting to know if every isoform exhibits a stress response.

Hsp10, a co-chaperone of Hsp60, known as chaperonin 10, is found in mitochondria, the Golgi apparatus, pancreatic secretory granules, zymogen granules (Velez-Granell et al., 1994), growth hormone pellets and red blood cells (Sadacharan et al., 2001). Together, Hsp10 and Hsp60 form a mitochondrial chaperone complex which plays an important role in protein quality control, mitochondrial protein folding and secretory protein aggregation (Corrao et al., 2014). The main roles of Hsp10 are in regulating cell signal transduction, the inflammatory immune response (Akyol et al., 2006) and so on. But there is very little available information on expression of Hsp10, and so far, only one subtype of Hsp10 has been found in salmonid fish (Andreassen et al., 2009).

Apoptosis is an active, ordered process that maintains the stability of the internal environment (Kerr et al., 1972). This process includes the removal of unwanted or abnormal cells in multicellular organisms. Previous studies indicate that apoptosis may be directly or indirectly related to various diseases such as tumours (Kerr et al., 1972) and autoimmune disease (Sanna et al., 2002; Szondy et al., 2003) and Hsp10 may be related to anti-apoptosis (Shan et al., 2003; Chaurasia et al., 2009).

In this study, we investigated the expression pattern of Hsp90a2b and Hsp10 mRNA and the apoptosis of blood cells at different water temperatures to better understand the mechanism of heat stress in rainbow trout.

\section{Materials and methods}

\section{Expermental fish}

Two hundred numbers of one-year old full-sibling inbreeding rainbow trouts $(O$. mykiss) with a mean weight of $400 \pm 11 \mathrm{~g}$ were used for the study. Specimens were obtained from the cage aquafarm in Liujiaxia Reservoir in China's Western Gansu Province and transported to the laboratory using a live fish transporter. These fish were temporarily placed in a 30001 indoor aerated water tank for one-week acclimatisation period at $18 \pm 0.2^{\circ} \mathrm{C}$. From this, 120 healthy fish were selected, divided evenly into six 3001 indoor circulation tanks and were subjected to heat stress. During acclimatisation as well as test periods, the water in the tanks was replaced partly using freshwater at same temperature as in the tanks $\left( \pm 0.2^{\circ} \mathrm{C}\right)$ every day. Light : dark photoperiod of $12 \mathrm{~h}: 12 \mathrm{~h}$ was maintained and fish were fed twice daily. All animal husbandry procedures and protocols complied with the requirements outlined by the Animal Experimentation Ethics Committee at Gansu Agricultural University, China.

\section{Heat treatment and sample collection}

Prior to temperature-rise test, 10 fish were randomly (10 out of 20) caught from one of the six tanks to act as control samples and narcotised using $0.05 \mathrm{~g} \mathrm{l}^{-1} \mathrm{MS} 222$. Caudal vein blood samples were collected, in heparinised vials and samples were preserved at $4^{\circ} \mathrm{C}$. Samples of liver, mid-kidney, gill, spleen, heart, brain and muscle (50-100 $\mathrm{mg}$ ) were rapidly collected, transferred to $2 \mathrm{ml}$ cryo tubes and stored in liquid nitrogen. After collection of samples from the control group, the water was slowly heated at a constant heating rate of $1^{\circ} \mathrm{C}$ per day until temperatures reached $26^{\circ} \mathrm{C}$. During this period, at $21,23,24,25$ and $26^{\circ} \mathrm{C}, 10$ fish of each group at respective temperature were sampled (there were 20 fishes in a tank). Sampling of each group was carried out at the same time point (08 $00 \mathrm{hrs)}$ of the sampling day to eliminate errors caused by the daily cycle. Ultimately, five samples from each group were used to analyse the expression level of mRNA and 5 samples for blood cell apoptosis analysis.

\section{Total RNA extraction and $c D N A$ synthesis}

Total RNA was extracted using a Trizol kit (TransGen, Beijing, China), dissolved in $50 \mu$ l RNase-free water and then stored at $-80^{\circ} \mathrm{C}$. RNA concentration and purity were assessed using 260:280 and 260:230 ratios using ultra-micro spectrophotometer (Implen, NanoPhotometer ${ }^{\circledR}$ Pearl 360, Waltham, Germany); RNA integrity was assessed by $1 \%(\mathrm{~m} / \mathrm{v})$ gel electrophoresis. One microliter sample of total RNA was reverse-transcribed to $20 \mu \mathrm{l}$ cDNA employing a reverse transcription kit (TaKaRa, Dalian, China). The cDNA was stored at $-20^{\circ} \mathrm{C}$ for real-time fluorescence quantitative experiments.

\section{Real time quantitative PCR (RT-qPCR)}

Amplification primers were designed for the Hsp10 gene (GenBankAccession no. BT043672.1) and Hsp90a2b gene (GenBank Accession no. KC150878) using Primer Premier 5.0 software (Premier Biosoft, Canada) according to Rainbow Trout cDNA sequences reported in NCBI that were located using the Atlantic Salmon Hsp DNA sequences (Garcia et al., 2013). The reference gene was $\beta$-actin (Ojima et al., 2005), which showed no response to temperature in preliminary experiments and primer sequences are shown in Table 1.

RT-qPCR experiments were performed using a Roche 480 II system (Roche, Switzerland) and Green SYBR I fluorescence embedding method. Each RT-PCR used a $20 \mu \mathrm{l}$ system, including $2 \mu \mathrm{l}$ 1:9 diluted cDNA template $(<100 \mathrm{ng}), 0.4 \mu \mathrm{l}$ forward and $0.4 \mu \mathrm{l}$ reverse primer, $10 \mu \mathrm{l} \mathrm{SYBR}{ }^{\circledR}$ Premix Ex Taq $^{\mathrm{TM}}$ II reverse transcriptase 
Table 1. Primers used for the relative quantitative RT-PCR

\begin{tabular}{llll}
\hline Gene & Accession no. & Primer sequence & Product length (bp) \\
\hline Hsp90 $\alpha$ & KC150878 & F: 5'-AAGGAGAAGGATGGGGAAGAAGGA-3' & \\
& & R: 5'-TTCTTCTTCTTCTTCTTGTCACCG-3' & 250 \\
\hline Hsp10 & BT043672.1 & F: 5'-AGGCTCCACCAACCAGAAAG-3' & 131 \\
& & R: 5'-CAGCATCACGGAACAGGAAG-3' & 165 \\
\hline$\beta$-actin & AB196465 & F: 5'-TGGGGCAGTATGGCTTGTATG-3' & \\
& & R: 5'-CTCTGGCACCCTAATCACCTCT-3' & \\
\hline
\end{tabular}

F: Forward primer; R: Reverse primer.

$(10 \mu \mathrm{m})(\mathrm{TaKaRa})$ and $7.2 \mu \mathrm{l}$ Rase-free $\mathrm{ddH}_{2} \mathrm{O}$. Analysis of the fluorescence quantitative dissolution curve was used to determine the existence of the primer dipolymer and the accuracy of the PCR products. The RT-qPCR reaction conditions were as follows: $95^{\circ} \mathrm{C}$ for $2 \mathrm{~min}$; and then 40 cycles of $95^{\circ} \mathrm{C}$ for $15 \mathrm{~s} ; 60^{\circ} \mathrm{C}$ (Hsp90a2b) or $62^{\circ} \mathrm{C}$ (Hsp10) for $30 \mathrm{~s}, 72^{\circ} \mathrm{C}$ for $30 \mathrm{~s}, 95^{\circ} \mathrm{C}$ for $5 \mathrm{~s}, 65^{\circ} \mathrm{C}$ for $60 \mathrm{~s}$ and $4^{\circ} \mathrm{C}$ for $30 \mathrm{~s}$.

\section{Blood cell apoptosis}

Blood samples collected (with anticoagulant) were first centrifuged at $200 \mathrm{~g}$ for $15 \mathrm{~min}$, then the supernatants were discarded and the remaining blood cells were washed twice in cold phosphate buffered saline (PBS). Blood cells at concentration of $1 \times 10^{6}$ cells $\mathrm{ml}^{-1}$ were collected using $1 \times$ Annexin $\mathrm{V}$ binding buffer and were then processed with an Annexin V-FITC cell apoptosis detection kit (BestBio, Shanghai, China). All blood samples were analysed for apoptosis using flow cytometry (BECKMAN COULTER ${ }^{\circledR}$ Cell Lab Quanta ${ }^{\mathrm{TM}}$, USA) and FlowJo analysis software.

\section{Data analysis}

qPCR cycle thresholds $(\mathrm{Ct})$ of the target and housekeeping genes were calculated as the average of the triplicates (per tissue sample). The Hsp90a2b and Hsp10 mRNA expressions were calculated as relative folds of the expression of the housekeeping gene ( $\beta$-actin) by using the formula of $2^{-\Delta \mathrm{Ct}}$ (Zhang et al., 2014). These experiments also indicated that amplification efficiencies of $\beta$-actin, Hsp90a2b and Hsp10 genes did not violate assumptions of the $\Delta \Delta \mathrm{Ct}$ method. One-way analysis of variance (ANOVA) followed by Duncan's multiple range test at $\mathrm{p}<0.05$ was performed using SPSS 19.0 software (IBM, Armonk, NY, USA) to evaluate the statistical significance of the mRNA expression levels and the apoptosis rate of blood cells. All the results are shown as mean \pm standard error $(n=5)$.

\section{Results}

\section{Effects of heat stress on Hsp90a2b mRNA expression}

Expressions of Hsp90a2b were generally upregulated with increasing water temperature in gill, mid-kidney, brain, heart and muscle (Fig. 1). In the liver, compared to the control group $\left(18^{\circ} \mathrm{C}\right)$, Hsp90a2b expression increased rapidly at $21^{\circ} \mathrm{C}(\mathrm{p}<0.05)$ and then showed a significant decrease at 23 and $24^{\circ} \mathrm{C}$ when compared with $21^{\circ} \mathrm{C}$ $(\mathrm{p}<0.05)$ and finally a significant increase at 25 and $26^{\circ} \mathrm{C}$ $(p<0.05)$. There was an expression peak at $24^{\circ} \mathrm{C}$ in the spleen, which was significantly higher compared to the level at 18,21 and $23^{\circ} \mathrm{C}(\mathrm{p}<0.05)$ and was not marked different than that at 25 and $26^{\circ} \mathrm{C}$. Moreover, the fish responded to heat stress in a tissue-specific manner. Hsp90a2b expression was lower in gill tissue throughout the experiments, and higher in the brain and heart.

\section{Effects of heat stress on Hsp10 mRNA expression}

Hsp10 expression showed an irregular but overall increasing tendency in gill, spleen and mid-kidney, or showed a wave-like increasing pattern in liver, heart and muscle (Fig. 2). Highest expression was recorded at $26^{\circ} \mathrm{C}$ in all tissues. In the brain, there was no significant difference ( $p>0.05$ ) between different water temperature groups and although expression at $26^{\circ} \mathrm{C}$ was highest, this was only slightly higher than that at $18^{\circ} \mathrm{C}(1.1$-fold $)(\mathrm{p}>0.05)$. There was an expression peak at $25^{\circ} \mathrm{C}$ in the spleen, which was significantly higher compared to the level at 18, 21 and $23^{\circ} \mathrm{C}(\mathrm{p}<0.05)$ and was not marked different from that at 24 and $26^{\circ} \mathrm{C}(\mathrm{p}>0.05)$. Hsp10 was also expressed in a tissue specific manner and the fundamental expression levels at $18^{\circ} \mathrm{C}$ were relatively higher in the liver and heart than that in other tissues. It is worth mentioning that the basal expression at $18^{\circ} \mathrm{C}$ of $\mathrm{Hsp} 10$ in muscle was significantly lower than that in the liver, heart, mid-kidney and brain $(\mathrm{p}<0.05)$, but the expression increased rapidly at $26^{\circ} \mathrm{C}$.

\section{Blood cell apoptosis induced by heat stress}

Apoptosis rate of blood cells had two peaks, at 21 and $25^{\circ} \mathrm{C}$ respectively (Fig. 3). The apoptosis rate at $21^{\circ} \mathrm{C}$ was significantly higher than that at 18 and $23^{\circ} \mathrm{C}(\mathrm{p}<0.05)$ and at $25^{\circ} \mathrm{C}$ was significantly higher than any other group $(\mathrm{p}<0.05)$. The apoptosis rate at $23^{\circ} \mathrm{C}$ was not significantly different compared with $18^{\circ} \mathrm{C}(\mathrm{p}>0.05)$ but was smaller compared with 21 and $24^{\circ} \mathrm{C}(\mathrm{p}<0.05)$. 




Fig. 1. Expression level of Hsp90 $\alpha$ mRNA in different tissues at different water temperatures. Different upper case letters indicate a significant difference between different tissues at the same water temperature $(\mathrm{p}<0.05, \mathrm{n}=5$, mean $\pm \mathrm{SE}$ ). Different lowercase letters indicate a significant difference between different water temperatures for the same tissue $(\mathrm{p}<0.05, \mathrm{n}=5, \mathrm{mean} \pm \mathrm{SE})$

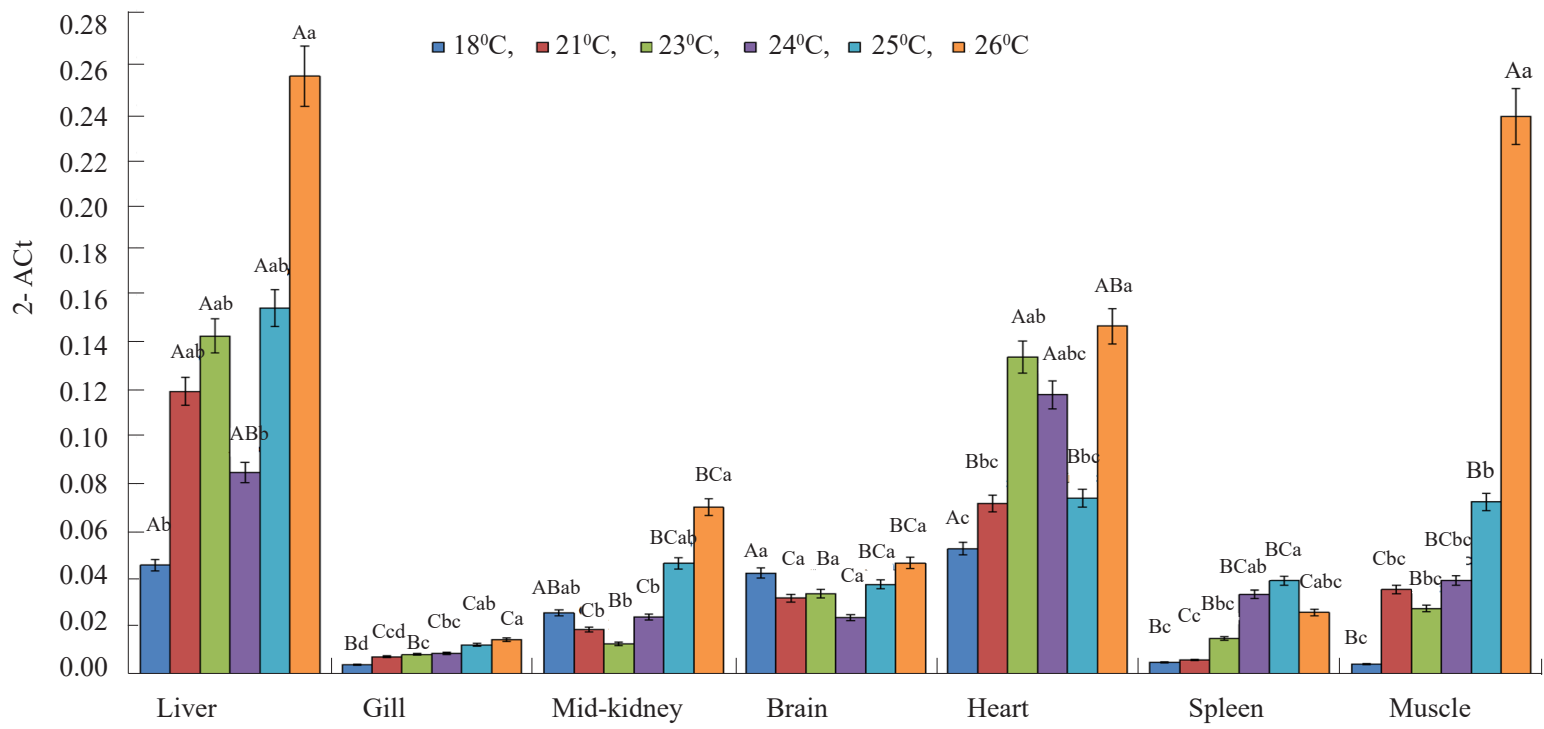

Fig. 2. Expression level of Hsp10 mRNA in different tissues under different water temperatures. Different upper case letters indicate a significant difference between different tissues at the same water temperature $(p<0.05, n=5$, mean $\pm S E)$. Different lowercase letters indicate a significant difference between different water temperatures for the same tissue $(\mathrm{p}<0.05, \mathrm{n}=5$, mean $\pm \mathrm{SE})$

\section{Discussion}

In general, in the current study, raising water temperature increased Hsp90a2b expression in all tissues, which was consistent with a previous study on Hsp90b expression in acute heat stress ( $\mathrm{Li}$ et al., 2016). The current study also showed that the mRNA expression levels of Hsp90a2b after $25^{\circ} \mathrm{C}$ and of $\mathrm{Hsp} 10$ at $26^{\circ} \mathrm{C}$ were always significantly higher compared to the level before the heat stress test $\left(18^{\circ} \mathrm{C}\right)$ in all tissues tested. In addition, apoptosis rate of blood cells was significantly higher at $25^{\circ} \mathrm{C}$ than at other temperatures. Therefore it could be presumed that, $25^{\circ} \mathrm{C}$ may be the key temperature point for rainbow trout under heat stress.

In vertebrates, the liver is involved in detoxification, immune defense and hormone synthesis. Shi et al. (2015) suggested that the liver is better able to respond to heat 

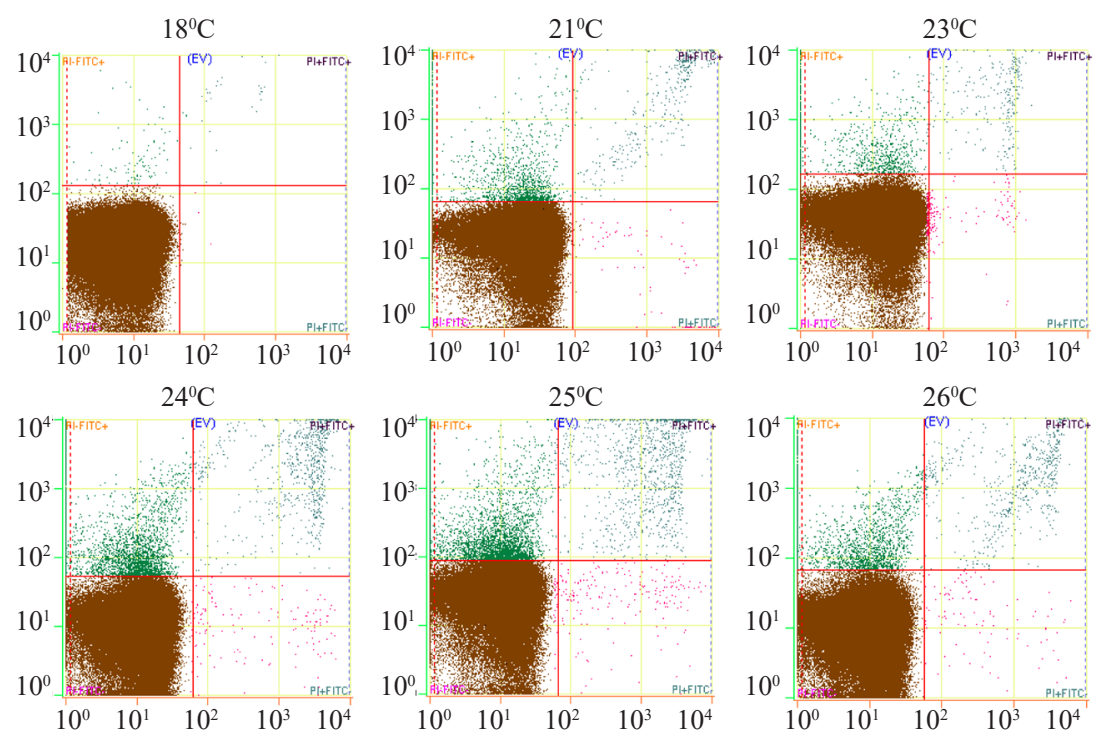

(a)

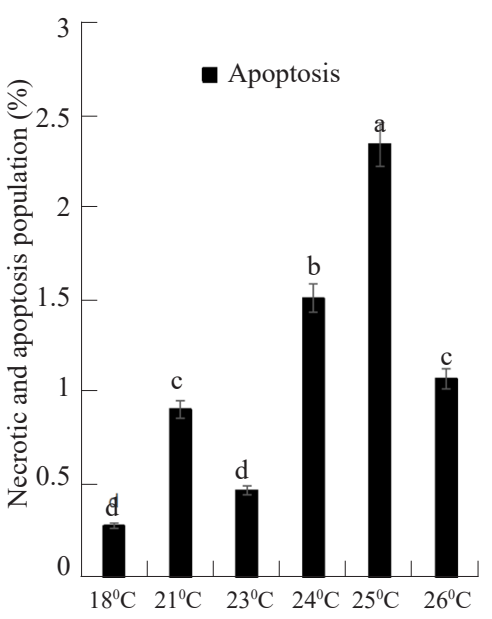

(b)

Fig. 3. Blood cell apoptosis rate in rainbow trout at different water temperatures. (a) Plot for living cells (FITC-/PI-); necrotic cells $\left(\mathrm{FITC}^{+} / \mathrm{PI}^{+}\right)$; and apoptotic cells $\left(\mathrm{FITC}^{+} / \mathrm{PI}\right)$; (b) Blood cell apoptosis rate. Different letters indicate significant differences $(\mathrm{p}<0.05, \mathrm{n}=10$, mean \pm SE)

stimuli than other tissues in rainbow trout, which indicates its importance and is possibly due to the higher expression efficiency of Hsps in liver. Our study indeed found that expression levels of both Hsp90a2b and Hsp10 in the liver were significantly higher than in other tissues at $21^{\circ} \mathrm{C}$, consistent with a previous study which found that expression of Hsp90, Hsp60 and Hsp47 in liver was significantly higher than in other tissues after heat stress (Rendell et al., 2006; Shi et al., 2015; Wang et al., 2015). Especially, in our study, Hsp90a2b expression in liver and the blood cell apoptosis rate showed rapid increase in response at $21^{\circ} \mathrm{C}$ and therefore it is inferred that the heat shock response in rainbow trout had already occurred at $21^{\circ} \mathrm{C}$ and maybe, tolerance to heat stress may mainly depend on the degree of liver damage. But, Jia et al. (2016), found that Hsp90a2b in rainbow trout hepatocytes was unaffected when following an acute heat shock $(1 \mathrm{~h}$ at $\left.25^{\circ} \mathrm{C}\right)$ compared to a control treatment $\left(12^{\circ} \mathrm{C}\right)$. However, this experiment was conducted using cultured hepatocytes (not in vivo), where hepatocytes were treated by an acute heat shock.

The gill, is an important organ having roles in respiration, excretion and regulation of osmotic pressure in fish. As an organ directly in contact with the environmental medium, frequent stimulation may enhance its adaptability and tolerance to temperature and reduce sensitivity to change in water temperature. Shi et al. (2015) found that Hsp60 expression in gill tissue was not changed at the beginning in a continuous heat stress of $25^{\circ} \mathrm{C}$ until $8 \mathrm{~h}$ later. In the present study, the expression of Hsp90 $\alpha$ in the gills gradually increased from 18 to $24^{\circ} \mathrm{C}$, but there was no significant difference between the above groups, until after $25^{\circ} \mathrm{C}\left(25\right.$ and $\left.26^{\circ} \mathrm{C}\right)$, which were significantly higher than that of above groups. Expression of Hsp10, also was significantly higher only after $25^{\circ} \mathrm{C}$, compared with $21,23,24$ as well as $18^{\circ} \mathrm{C}$. All these indicate that gill tissue had good resistance to heat shock and that marked expression response occurred only when the gill tissue was hyperirritable during heat stress, which usually happens after $25^{\circ} \mathrm{C}$.

In the brain, there is substantial evidence that high temperature stress significantly increases expression of Hsp70, Hsp60, Hsp90 $\beta$ and Hsp40 mRNA (Nowak et al., 1990; Dyer et al., 1991; Li et al., 2016). In our study, the expression of Hsp90a2b in the brain increased rapidly with increasing temperature and was higher than $\mathrm{Hsp} 10$ at all temperature points in the brain, but Hsp10 did not change significantly, suggesting that Hsp90a2b plays a far greater role in heat shock protection in the brain than Hsp10.

The mid-kidney is involved in regulating the body's osmotic pressure. In this study, Hsp90a2b expression in the mid-kidney gradually increased with increasing water temperature. However, expression of Hsp10 was not significantly different between groups at 18, 21, 23, 24 and $25^{\circ} \mathrm{C}$. Only at $26^{\circ} \mathrm{C}$, it was significantly higher compared 
to the level before $25^{\circ} \mathrm{C}(\mathrm{p}<0.05)$. This may be because the Hsp10 in the mid-kidney is heat-insensitive and major protection is provided by Hsp90 $\alpha$ and other Hsps.

Fish metabolic rate largely depends on temperature and the metabolic needs of the tissue are met through the circulatory system (Korajoki and Vornanen, 2014). The heart therefore plays an extremely important role in fish metabolism. In this research, at $26^{\circ} \mathrm{C}$, the $\mathrm{Hsp} 90 \alpha$ expression in heart increased rapidly and both Hsp90a2b and Hsp10 expressions reached the maximum value. We concluded that heart injury is serious at this time and therefore stimulates production of Hsp90a2b and Hsp10 to maintain normal cardiac function. In muscle, whether Hsp90a2b or Hsp10, their fundamental expressions at $18^{\circ} \mathrm{C}$ were lower, but the levels increased rapidly at $26^{\circ} \mathrm{C}$, which indicates that muscle is more tolerant of heat stress.

The spleen is the largest lymphoid organ in the fish and is involved in filtration, removal of antigens and other foreign bodies from the blood and promoting the proliferation of $\mathrm{T}$ and B lymphocytes. In the present study, the expressions of both Hsp90a2b and Hsp10 in the spleen had a peak at 24 or $25^{\circ} \mathrm{C}$. This may be because the early heat stress was so hyperirritable for the spleen that the syntheses of Hsp10 and Hsp90a2b were inhibited. This observation is similar to the results of Huang et al. (2015) who found that Hsp10 expression in the spleen of bastard halibut Paralichthys olivaceus decreased rapidly when water temperature was raised to $32^{\circ} \mathrm{C}$.

Heat stress induces apoptosis through activation of reactive oxygen species (ROS) and mitochondrial signaling pathways (Li et al., 2009). Previous studies have shown that Hsp10 inhibits apoptosis via the regulation of signal transduction (Shan et al., 2003; Schlieper et al., 2007; Fan et al., 2009). We found that the change in blood cell apoptosis rate were almost exactly opposite to the expression of Hsp10 in the heart, maybe suggesting an anti-apoptotic role of Hsp10.

Expression of Hsps is closely related to environmental stress intensity and different Hsps have different functions and main target organ. The results of the study can be used to better understand the mechanism of heat stress in fish (Cara et al., 2005; Wang et al., 2007; Roberts et al., 2010) and to quantitatively measure the degree of the environmental stress. In this study, the results showed that the heat shock response in rainbow trout had already occurred at 21 and $25^{\circ} \mathrm{C}$, may be the key temperature point for rainbow trout under heat stress and that tolerance to heat stress may mainly depend on the degree of liver damage. The results provide a reference for further research on response to heat stress in rainbow trout.

\section{Acknowledgements}

This work was supported by the Discipline Construction Fund Project of Gansu Agricultural University (No. GAU-XKJS-2018- 025). The first two authors contributed equally to this work and should be considered co-first authors.

\section{References}

Akyol, S., Gercel-Taylor, C., Reynolds, L. C. and Taylor, D. D. 2006. HSP-10 in ovarian cancer: Expression and suppression of T-cell signaling. Gynecol. Oncol., 101(3): 481-486.

Andreassen, R., Lunner, S. and Hoyheim, B. 2009. Characterisation of full-length sequenced cDNA inserts (FLIcs) from Atlantic salmon (Salmo salar). BMC Genomics, 10(1): 502-510.

Basu, N., Todgham, A. E., Ackerman, P. A., Bibeau, M. R., Nakano, K., Schulte, P. M. and Iwama, G. K. 2002. Heat shock protein genes and their functional significance in fish. Gene, 295(2): 173-183.

Boone, A. N. and Vijayan, M. M. 2002. Glucocorticoid-mediated attenuation of the hsp70 response in trout hepatocytes involves the proteasome. Am. J. Physiol. Regul. Integr. Comp. Physiol., 283(3): R680-R687. DOI:10.1152/ ajpregu.00125.2002.

Cara, J. B., Aluru, N., Moyano, F. J. and Vijayan, M. M. 2005. Food-deprivation induces HSP70 and HSP90 protein expression in larval gilthead seabream and rainbow trout. Comp. Biochem. Physiol., Part B, Biochem. Mol. Biol., 142(4): 426-431. DOI: 10.1016/j.cbpb.2005.09.005.

Chaurasia, A. K. and Apte, S. K. 2009. Overexpression of the groESL operon enhances the heat and salinity stress tolerance of the nitrogen-fixing cyanobacterium Anabaena sp. strain PCC7120. Appl. Env. Microbiol., 75(18):6008-6012. DOI: 10.1128/AEM.00838-09.

Corrao, S., Anzalone, R., Lo Iacono, M., Corsello, T., Di-Stefano, A., D’Anna, S. E., Balbi, B., Carone, M., Sala, A., Corona, D., Timperio, A. M., Zolla, L., Farina, F., de Macario, E. C., Macario, A. J. L., Cappello, F. and La Rocca, G. 2014. Hsp10 nuclear localisation and changes in lung cells response to cigarette smoke suggest novel roles for this chaperonin. Open Biol., 4(10): 140125-140139. doi: 10.1098/rsob.140125.

Dyer, S. D., Dickson, K. L., Zimmerman, E. G. and Sanders, B. M. 1991. Tissue-specific patterns of synthesis of heat-shock proteins and thermal tolerance of the fathead minnow (Pimephales promelas). Can. J. Zool., 69(8):2021-2027.

Fan, L., Ling, J., Ma, X., Cui, Y. and Liu, J. 2009. Involvement of HSP10 during the ovarian follicular development of polycystic ovary syndrome: Study in both human ovaries and cultured mouse follicles. Gynecol. Endocrinol., 25(6): 392-397. DOI:10.1080/09513590902730796.

Galea-Lauri, J., Latchman, D. S. and Katz, D. R. 1996. The role of the $90-\mathrm{kDa}$ heat shock protein in cell cycle control and 
differentiation of the monoblastoid cell line U937. Exp. Cell Res., 226(2): 243-254. DOI:10.1006/excr.1996.0225.

Garcia de la Serrana, D. and Johnston, I. A. 2013. Expression of heat shock protein (Hsp90) paralogues is regulated by amino acids in skeletal muscle of Atlantic salmon. Plos One, 8(9): e74295-e74309. DOI:10.1371/journal.pone. 0074295 .

Huang, L., Li, G., Mo, Z., Xiao, P., Li, J. and Huang, J. 2015. De novo assembly of the Japanese flounder (Paralichthys olivaceus) spleen transcriptome to identify putative genes involved in immunity. Plos One, 10(2), e0117642-e0117661. DOI:10.1371/journal.pone.0117642.

Jia, Y., Cavileer, T. D. and Nagler, J. J. 2016. Acute hyperthermic responses of heat shock protein and estrogen receptor mRNAs in rainbow trout hepatocytes. Comp. Biochem. Physiol. Part A, Mol. Integr. Physiol., 201: 156-161. DOI:10.1016/j.cbpa.2016.04.023.

Kerr, J. F. R., Wyllie, A. H. and Currie, A. R. 1972. Apoptosis: a basic biological phenomenon with wide-ranging implications in tissue kinetics. British J. Cancer, 26(4): 239-257. DOI:10.1038/bjc.1972.33.

Korajoki, H. and Vornanen, M. 2014. Species- and chamberspecific responses of $12 \mathrm{kDa}$ FK506-binding protein to temperature in fish heart. Fish Physiol. Biochem., 40(2): 539-549. DOI: 10.1007/s10695-013-9864-9.

Lindquist, S. and Craig, E. A. 1988. The heat-shock proteins. Annu. Rev. Genet., 22: 631-677.

Li, W., Li, Y., Guan, S., Fan, J., Cheng, C., Bright, A. M., Chinn, C., Chen, M. and Woodley, D. T. 2007. Extracellular heat shock protein-90 $\alpha$ : linking hypoxia to skin cell motility and wound healing. EMBO J., 26(5): 1221-1233. DOI:10.1038/sj.emboj.7601579.

Li, M. X., Huang, W. J., Wang, B., Liu, M., Zhang, Q., Yan, W., Zhu, Q., Luo, M., Zhou, Z. and Tian, D. A. 2009. Transcriptional up-regulation of FoxM1 in response to hypoxia is mediated by HIF-1. J. Cell. Biochem., 106(2): 247-256. DOI:10.1002/jcb.21996.

Li, Z., Liu, Z., Wang, Y. N., Kang, Y. J., Wang, J. F., Shi, H. N., Huang, J. Q. and Li, J. 2016. Effects of heat stress on serum cortisol, alkaline phosphatase activity and heat shock protein 40 and $90 \beta$ mRNA expression in rainbow trout Oncorhynchus mykiss. Biologia, 71(1): 109-115.

Nowak, T. S., Bond, U. and Schlesinger, M. J. 1990. Heat shock RNA levels in brain and other tissues after hyperthermia and transient ischemia. J. Neurochem., 54(2): 451-458. DOI:10.1111/j.1471-4159.1990.tb01893.x.

Ojima, N., Yamashita, M. and Watabe, S. 2005. Quantitative mRNA expression profiling of heat-shock protein families in rainbow trout cells. Biochem. Biophys. Res. Commun., 329(1): 51-57. DOI:10.1016/j.bbrc.2005.01.097.

Pirkkala, L., Alastalo, T. P., Zuo, X., Benjamin, I. J. and Sistonen, L. 2000. Disruption of heat shock factor 1 reveals an essential role in the ubiquitin proteolytic pathway.
Mol. Cell. Biol., 20(8): 2670-2675. doi: 10.1128/mcb.20. 8.2670-2675.2000.

Rendell, J. L., Fowler, S., Cockshutt, A. and Currie, S. 2006. Development-dependent differences in intracellular localisation of stress proteins (hsps) in rainbow trout, Oncorhynchus mykiss, following heat shock. Comp. Biochem. Physiol. Part D. Genomics Proteomics, 1(2): 238-252. DOI: 10.1016/j.cbd.2005.12.004.

Roberts, R. J., Agius, C., Saliba, C., Bossier, P. and Sung, Y. Y. 2010. Heat shock proteins (chaperones) in fish and shellfish and their potential role in relation to fish health: a review. $J$. Fish Dis., 33(10): 789-801. DOI:10.1111/j.1365-2761. 2010.01183.x.

Sadacharan, S. K., Cavanagh, A. C. and Gupta, R. S. 2001. Immunoelectron microscopy provides evidence for the presence of mitochondrial heat shock $10-\mathrm{kDa}$ protein (chaperonin 10) in red blood cells and a variety of secretory granules. Histochem. Cell Biol., 116(6): 507-517.

Sanna, M. G., da Silva Correia, J., Ducrey, O., Lee, J., Nomoto, K., Schrantz, N., Deveraux, Q. L. and Ulevitch, R. J. 2002. IAP suppression of apoptosis involves distinct mechanisms: the TAK1/JNK1 signaling cascade and caspase inhibition. Mol. Cell. Biol., 22(6): 1754-1766. DOI:10.1128/mcb.22.6.1754-1766.2002.

Schlieper, A., Anwar, M., Heger, J., Piper, H. M. and Euler, G. 2007. Repression of anti-apoptotic genes via AP-1 as a mechanism of apoptosis induction in ventricular cardiomyocytes. Pflugers Arch. Eur. J. Physiol., 454(1): 53-61. DOI: 10.1007/s00424-006-0180-4.

Shan, Y., Liu, T. J., Su, H., Samsamshariat, A., Mestril, R. and Wang, P. H. 2003. Hsp10 and Hsp60 modulate Bcl-2 family and mitochondria apoptosis signaling induced by doxorubicin in cardiac muscle cells. J. Mol. Cell. Cardiol., 35(9): 1135-1143. DOI:10.1016/s0022-2828(03)00229-3.

Shi, H. N., Liu, Z., Zhang, J. P., Kang, Y. J., Wang, J. F., Huang, J. Q. and Wang, W. M. 2015. Effect of heat stress on heat-shock protein (Hsp60) mRNA expression in rainbow trout Oncorhynchus mykiss. Genet. Mol. Res., GMR, 14(2): 5280-5286. DOI:10.4238/2015.May.18.20.

Szondy, Z., Sarang, Z., Molnar, P., Nemeth, T., Piacentini, M., Mastroberardino, P. G., Falasca, L., Aeschlimann, D., Kovacs, J., Kiss, I., Szegezdi, E., Lakos, G., Rajnavolgyi, E., Birckbichler, P. J., Melino, G. and Fesus, L. 2003. Transglutaminase $2^{-/-}$mice reveal a phagocytosis-associated crosstalk between macrophages and apoptotic cells. Proc. Natl. Acad. Sci., 100(13): 7812-7817. DOI:10.1073/pnas. 0832466100.

Velez-Granell, C. S., Arias, A. E., Torres-Ruiz, J. A. and Bendayan, M. 1994. Molecular chaperones in pancreatic tissue: the presence of cpn10, cpn60 and Hsp70 in distinct compartments along the secretory pathway of the acinar cells. J. Cell Sci., 107(Pt3): 539-549.

Verleih, M., Borchel, A., Krasnov, A., Rebl, A., Korytar, T., Kuhn, C. and Goldammer, T. 2015. Impact of thermal stress 
on kidney-specific gene expression in farmed regional and imported rainbow trout. Mar. Biotechnol., 17(5): 576-592.

Wang, Y. B., Xu, J. B., Sheng, L. X. and Zheng, Y. C. 2007. Field and laboratory investigations of the thermal influence on tissue-specific Hsp70 levels in common carp (Cyprinus carpio). Comp. Biochem. Physiol. Part A Mol. Integr. Physiol., 148(4): 821-827. DOI: 10.1016/j.cbpa. 2007.08.009.

Wang, Y. N., Liu, Z., Li, Z., Shi, H. N., Kang, Y. J., Wang, J. F., Huang, J. Q. and Li, J. 2015. Effects of heat stress on respiratory burst, oxidative damage and SERPINH1 (HSP47) mRNA expression in rainbow trout Oncorhynchus mykiss. Fish Physiol. Biochem., 42(2): 701-710. DOI: 10.1007/s10695-015-0170-6.

Zhang, L. L., Sun, C. F., Ye, X., Zou, S. M., Lu, M. X., Liu, Z. G. and Tian, Y. Y. 2014. Characterisation of four heat-shock protein genes from Nile tilapia (Oreochromis niloticus) and demonstration of the inducible transcriptional activity of Hsp70 promoter. Fish Physiol. Biochem., 40(1): 221-233. DOI:10.1007/s10695-013-9838-y. 